\title{
A point to evaluate in the COVID-19 pandemic process: Frailty
}

\author{
COVID-19 Pandemi Sürecinde Değerlendirilmesi Gereken Bir Nokta: Kırılganlık
}

Hatice Yüceler Kaçmaz ${ }^{1}$ Ayser Döner ${ }^{2 *}$, Özlem Ceyhan²

1.Department of Surgical Diseases Nursing, Erciyes University Health Sciences Faculty, Kayseri, Turkey.

2.Department of Internal Diseases Nursing, Erciyes University Health Sciences Faculty, Kayseri, Turkey.

\section{ABSTRACT}

Globally, as of September 16, 2020, COVID-19 had infected approximately 29 million people and caused the death of 930 thousand people around the world. While the whole world is at risk of COVID-19 infection, the elderly in particular represent the highest risk group. Those who are very old and frail and have cognitive impairment and multi-comorbidity, are the most vulnerable to the severe consequences of this infection. Frailty is a less well-known and often overlooked issue compared to other factors. In the world, the prevalence of frailty is seen to rise with the increase of the aging population, and the prevalence of frailty among the elderly people living in society is thought to be 4 to $59 \%$. The COVID-19 pandemic, which has affected the entire world, leads to the necessity of taking care of elderly individuals in nursing homes and care centers. The fact that most persons in such facilities are advanced in age, frail and have multi-comorbidity, makes the management of the care even more difficult. It is thought that there may be a potential relationship between frailty and the course of COVID-19 and deaths resulting from the infection. The need for a holistic assessment of not only the age of the patient but also the state of frailty, is emphasized to ensure the triage of elderly persons and resource allocation during COVID-19 pandemic process. This review was performed to raise awareness of the healthcare professionals on the importance of frailty among the elderly during the COVID-19 pandemic process and to provide general information about the instruments that can be used to measure the frailty status of the elderly, when managing the COVID-19 pandemic process.

Keywords: Coronavirus disease (COVID-19), frailty, old age

\section{Öz}

Küresel olarak, 16 Eylül 2020 tarihi itibariyle COVID-19 dünyada yaklaşık olarak 29 milyon insanı enfekte etmiş ve 930 bin insanın ise ölümüne neden olmuştur. Tüm dünya COVID-19 enfeksiyonu riski altındayken, özellikle yaşlıar en yüksek risk altında olan gruptur. Özellikle çok yaşlı, kırılgan, bilişsel bozukluk ve multikomorbiditeye sahip olanlar bu enfeksiyonun ciddi sonuçlarına karşı en savunmasız olanlardır. Diğer faktörlere kıyasla kırıganlık daha az bilinen ve göz ardı edilen bir konudur. Dünyada, yaşlanan nüfusun artmasıyla birlikte kırılganlık prevelansının da arttığı görülmekte ve toplumda yaşayan yaşlı bireylerdeki kırılganlık prevelansının \%4 59 olduğu düşünülmektedir. Tüm dünyayı etkisi altına alan COVID-19 pandemisi yaşlı bireyleri huzurevlerinde ve bakım merkezlerinde bakılmaya zorlamaktadır. Bu tür tesislerde çoğu kişinin ileri yaşta olması, genellikle kırılgan olması ve sıkıkla multikomorbiditeye sahip olması bakımın yönetimini daha da zorlaştırmaktadır. KIrılganlık ile COVID-19 'un seyri ve COVID-19 nedeniyle ölüm arasında potansiyel bir ilişki olabileceği düşünülmektedir. COVID-19 pandemi sürecinde yaşlı bireylerin triyajını ve kaynak tahsisini sağlama da sadece yaşın değil kırıganlık durumunun bütüncül bir şekilde değerlendirilmesi gerekliliğinin önemi vurgulanmaktadır. $\mathrm{Bu}$ derleme sağlık profesyonellerine COVID-19 pandemi sürecinde yaşlıarda kırılganlığın önemi konusunda farkındalık oluşturmak, COVID-19 pandemi sürecini yönetirken yaşlı bireylerin kırılganlık durumlarının ölçülmesi için yararlanılabilecek araçlar hakkında genel bilgi vermek amacıyla oluşturulmuştur.

Anahtar kelimeler: Koronovirüs hastalı̆ı̆ (COVID-19), kırılganlık, yaşlılık

Received: 06.03.2021 Accepted: 17.04.2021 Published (Online): 30.08.2021

*Corresponding Author: Ayser Döner. Department of Internal Diseases Nursing, Erciyes University

Health Sciences Faculty, 38000 Kayseri, Turkey, +903524379281, ayserdoner@erciyes.edu.tr

ORCİ: 0000-0002-3450-7219

To cited: Yüceler Kaçmaz H, Döner A, Ceyhan Ö. A point to evaluate in the COVID-19 pandemic process: frailty. Acta Med. Alanya 2021;5(2):203-208 doi:10.30565/medalanya.891622 


\section{INTRODUCTION}

$T^{\text {tin }}$ he COVID-19 (coronavirus disease) cases caused by the newly-identified SARS-CoV-2 (Severe Acute Respiratory Syndrome causing Coronavirus 2) first appeared in Wuhan, China in December 2019 [1]. This rapidly spreading disease was recognized as a pandemic, in other words, a global epidemic, by the World Health Organization (WHO) in March 2020 [2]. As of September 16, 2020, COVID-19 has infected approximately 29 million people and caused the death of 930 thousand persons around the world [3]. It appears that the majority of COVID-19 cases are individuals aged 65 and over, and that the mortality rate due to COVID-19 increases exponentially with age (3.6\% between $60-69$ years of age, $8.0 \%$ between $70-79$ years of age, and $14.8 \%$ between 80 years and over) [4]. In addition, it has been determined that the mortality rate increases even more among elderly individuals with chronic diseases, such as cardiovascular disease, diabetes, respiratory system diseases, hypertension, etc. [5,6]. Frailty is one of the conditions that increases mortality and causes serious clinical symptoms among elderly individuals with COVID-19 $[7,8]$.

\section{FRAILTY}

Frailty is a concept that has physical, cognitive and emotional dimensions and is difficult to define $[9,10]$. It is one of the most common geriatric syndromes, is defined as $[11,12]$ "a clinical condition characterized by weakness, vulnerability, functional regression, increase of dependency and disability in daily life activities, and decreased resistance to stressors, which develops due to the decrease in physiological reserves with aging" $[13,14]$. Although frailty, which is a complex condition, increases with age, it may also be seen among young adult individuals $[13,15]$.

The number of studies conducted to determine the prevalence of frailty has increased with the rise in numbers of the aging population [16]. A systematic review performed to determine the prevalence of frailty among elderly persons living in society found that $10.7 \%$ of these are frail, and the prevalence of frailty ranges from $4 \%$ to $59 \%$ [17]. In a study conducted with 906 elderly persons living in Kayseri, the prevalence of frailty was determined to be $27.8 \%$, according to the Fried Frailty Index and $10 \%$ according to the FRAIL scale [18]. In the study by Özdemir et al. (2017), the prevalence of frailty among geriatric and hospitalized patients aged 65 years and over is $63.1 \%$ to $91.2 \%$ [19]. Although the incidence of frailty increases with age, frailty is more common among women, individuals with low socioeconomic levels and inactive persons $[11,20]$. Frailty, which increases mortality and morbidity rates [7,21-23], causes falls [24], delirium [25], disability [26] and, long-term hospitalizations [22] among elderly individuals. In addition, it adversely affects the quality of life of elderly persons and increases the burden and cost of care [27,28]. Genetics/ epigenetics, acute-chronic diseases, chronic inflammation and environmental factors, such as stress, malnutrition, etc., play an important role in the etiology of frailty, which is a dynamic condition $[7,12,28]$.

\section{Stages of Frailty}

Frailty is generally classified into three stages: pre-frail period, frail period and severe frail period. The symptoms seen in each period differ from another. Despite the decrease in physiological reserves during the pre-frail period, which is a clinically quiet period, it is sufficient to cope with stressors and there is a potential for a full recovery. Individuals during this period have two or fewer risk factors. In the frail period, functional capacity is progressively decreasing. Due to the decrease in physiological reserves, the healing process takes a long time and full recovery is not achieved. Coping with stress is insufficient in the frail period when individuals have three or more risk factors. The severe frail period is the stage in which frailty complications increase, the capacity to withstand progressive stress decreases, and disability and death are seen $[20,29]$.

\section{FRAILTY MEASURING INSTRUMENTS}

It is emphasized that it is very important to evaluate the frailty of individuals in the management of COVID-19 cases [21,30]. Various instruments have been developed to determine frailty [10]. The most commonly used instruments include the Clinical Frailty Scale (CFS) [31], the Fried Frailty Scale (FFI) [32], the FRAIL scale [33], the Study of Osteoporotic Fractures (SOF) [34] and the 
Table 1. Most Frequently used Frailty Measuring Instruments

\begin{tabular}{|c|c|c|c|c|}
\hline INSTRUMENTS & ITEMS & CLASSIFICATION & POPULATION & EXPLANATION \\
\hline $\begin{array}{l}\text { Clinical Frailty Scale- } \\
\text { CFS }\end{array}$ & 70 items & $\begin{array}{l}7 \text { categories } \\
\text { *Very healthy } \\
\text { *Healthy } \\
\text { " Healthy with comorbid } \\
\text { diseases treated } \\
\text { * Invulnerable view } \\
\text { * Slightly fragile } \\
\text { * Moderately fragile } \\
{ }^{*} \text { Severe / severely fragile }\end{array}$ & The elderly & $\begin{array}{l}\text { Due to the high number of items, it } \\
\text { is not practical to apply in the clinical } \\
\text { setting and a comprehensive geriatric } \\
\text { evaluation is required when using the } \\
\text { scale. }\end{array}$ \\
\hline Fried Frailty Scale -FFI & 5 criteria & $\begin{array}{l}3 \text { categories } \\
{ }^{*} \text { Normal } \\
{ }^{*} \text { Pre-frail } \\
{ }^{*} \text { Frail } \\
\end{array}$ & The elderly & $\begin{array}{l}\text { The scale is applied face to face and } \\
\text { requires some physical examination } \\
\text { techniques. }\end{array}$ \\
\hline FRAIL scale & 5 criteria & $\begin{array}{l}3 \text { categories } \\
{ }^{*} \text { Healthy } \\
\text { *Pre-frail } \\
{ }^{*} \text { Frail }\end{array}$ & $\begin{array}{l}\text { Individuals between the } \\
\text { ages of } 49-65 \text { / } \\
\text { The Elderly }\end{array}$ & $\begin{array}{l}\text { This scale can be applied by phone } \\
\text { or by itself without face-to-face } \\
\text { examination. }\end{array}$ \\
\hline $\begin{array}{l}\text { Study of Osteoporotic } \\
\text { Fractures -SOF }\end{array}$ & 3 criteria & $\begin{array}{l}3 \text { categories } \\
{ }^{*} \text { Normal } \\
{ }^{*} \text { Pre-frail } \\
{ }^{*} \text { Frail }\end{array}$ & $\begin{array}{l}\text { Elderly people living in } \\
\text { the community }\end{array}$ & $\begin{array}{l}\text { The scale is applied face to face and } \\
\text { requires some physical examination } \\
\text { techniques. }\end{array}$ \\
\hline $\begin{array}{l}\text { Edmonton Frailty Scale- } \\
\text { EFS }\end{array}$ & 10 domain & $\begin{array}{l}5 \text { categories } \\
{ }^{*} \text { Not fragile } \\
\text { * Sensitive } \\
\text { * Slightly fragile } \\
{ }^{*} \text { Moderately fragile } \\
\text { * Extremely fragile }\end{array}$ & The elderly & $\begin{array}{l}\text { The scale was developed for use by } \\
\text { healthcare professionals who are not } \\
\text { experts in geriatrics and gerontology } \\
\text { in hospitalized elderly patients. } \\
\text { The scale is applied face to face and } \\
\text { requires some physical examination } \\
\text { techniques. }\end{array}$ \\
\hline
\end{tabular}

\section{Edmonton Frailty Scale (EFS) [35] (Table 1).}

CFS developed by Rockwood et al. (2005) consists of 70 items. The frailty status of individuals is interpreted in seven categories [31]. It has been confirmed that CFS is an instrument that can provide very useful information in the clinical use for prioritization, such as triage in emergency services [36]. In the COVID-19 Guide presented by the National Institute for Health and Care Excellence (NICE), the use of CFS is recommended in the assessment of frailty during intensive care management [37]. However, although its application in the clinical setting is not practical [34], a comprehensive geriatric evaluation is required when using the scale [35].

Weight loss, exhaustion, physical activity, walking speed and handgrip strength are evaluated with the FFI developed by Fried et al. (2001). The individuals who meet three or more of these five criteria are considered to be frail, those who meet one or two criteria as pre-frail, and the individuals who do not meet any criteria are considered normal [32].

10 domains (cognitive status, general health status, functional independence, social support, drug use, nutrition, mood, continence and functional performance) are evaluated with the EFS which was developed by Rolfson et al. (2006) to determine the frailty of the elderly, for use by the healthcare professionals who are not experts in geriatrics and gerontology. Frailty levels are grouped into 5 categories with the scale, used to evaluate the frailty of the elderly hospitalized patients [35].

Morley et al. (2012) developed the FRAIL scale to assess the frailty states of individuals aged 4965 . With the scale, it is aimed to determine the frailty at an early stage and thus slow down the development rate of frailty. Each letter in the word FRAIL represents a frailty criterion (F: Fatigue, $R$ : Resistance, A: Ambulation, I: Illness, L: Loss of weight) [33]. Although the scale was first created to determine the frailty of middle-aged individuals, subsequent studies showed that the FRAIL scale 
was a reliable scale for determining the frailty of elderly individuals [38-40]. This scale can be applied by phone or by the individual, without face-to-face examination [33].

The SOF developed by Ensrud et al. (2008) is a scale that can be easily applied to elderly persons living in society. With this scale, unintentional weight loss, decrease in energy level and low mobility (using the chair test) are evaluated. However, since it is not appropriate to apply the chair test to hospitalized individuals, this scale is not recommended to be applied to the hospitalized patients. On the scale, 0 point are evaluated as normal, 1-2 points as pre-frail, and 3 or more points as frail [34].

In addition, it is recommended that the measuring instruments related to frailty should not be used solely when providing health care services to elderly individuals. Within the scope of a patientcentered approach, frailty- measuring instruments are recommended to be used together with factors such as the severity of the disease, the probability that the intervention will be successful and the state of frailty [41].

\section{COVID-19 AND FRAILTY}

In reviewing the literature, it is thought that there may be a potential relationship between frailty and the course of COVID-19 and deaths resulting from the pandemic. A study conducted by Baker et al. (2020) found that the patients who died due to COVID-19 had a high level of frailty [42]. In a cohort study by Brill et al. (2020), it was determined that most of the patients who died as a result of COVID-19 were elderly individuals and their frailty levels were higher than the surviving patients [43]. Similarly, another cohort study found that the frailty scores of organ transplant recipients who died due to COVID-19 were higher than those of the surviving patients, and that frailty was associated with death from COVID-19 [44]. It is supported by the studies that patients who die after contracting COVID-19 are frail individuals, although the number of these studies at present time is low. In a study conducted by Bellelli et al. (2020) to determine the role of frailty among the COVID-19 patients, it was discovered that frailty was associated with hospital mortality and intensive care admission [45]. In a retrospective observational study conducted by Turner et al. (2020) with palliative care patients, it was revealed that the level of frailty was associated with the course of COVID-19 disease and the duration of death [46]. In a retrospective observational study conducted to determine the relationship between the frailty and mortality rate of the elderly people hospitalized for COVID-19, age and frailty were found to have a weak positive relationship with mortality [47]. For this reason, during the COVID-19 pandemic, it is one of the recommended practices to evaluate the frailty of the elderly in particular.

Early life, middle life and late-life predictors and risk factors (e.g. genetic, epigenetic, psychological, socio-economic, lifestyle characteristics, frailty, nutritional status, multiple morbidity and medication) should be taken into account to more accurately explain the diversity in the aging of the population [9]. With the evaluation of frailty, which is found among these, the functional status of the patients can be closely monitored and elderly individuals who require special interventions can be identified, in order to reduce the risk of negative consequences [8].

Moreover, in the event of a pandemic such as COVID-19, screening of frailty and monitoring of changes in the health and frailty status of the elderly can be very useful in assessing the disease severity and the likelihood of successful intervention and directing patients to appropriate points, as well as preventing the resulting hospital occupancy [8].

Determining the factors related to frailty, preventing frailty and developing the appropriate protocols for a treatment plan, are also very important for the economic situation of countries [16]. For ensuring proper triage and resource allocation of elderly individuals during the COVID-19 pandemic, the importance of a holistic evaluation of not only the age of the patient, but also the frailty situation and the balance of benefit-harm by taking into account the patient's comorbidities, are also emphasized [48].

Prevention of frailty results in the aging of individuals in a healthy and desirable way [49]. For this reason, especially during the epidemic progression in the world, pre-frail individuals should be identified at an early stage and 
necessary measures should be taken to reduce or prevent the progress towards frailty [50]. Frailty screening should be performed as early as possible to evaluate the frailty of the elderly persons in the community by health care professionals who take part in the care of the frail elderly individuals [24].

Finally, as suggested in the conveyed studies, the frailty situation can be reversed by exercise (strength, cardiovascular exercise), adequate protein intake, vitamin D supplements, nutritional supplements, health education, counseling, special comprehensive geriatric assessment, home visits, treatment of anemia, depression and immunization $[7,16,28]$.

\section{CONCLUSION AND RECOMMENDATION}

It is known that COVID-19 infections, which negatively affect human health all over the world, pose a greater threat to the elderly. Frailty, which is one of the criteria used to evaluate the healthy aging status of elderly persons, is also seen as one of the important evaluation parameters in the COVID-19 pandemic process. Screening, early detection, stage determination, careful monitoring and prevention of frailty are very important in health management and referral of elderly persons who have experienced a COVID-19 infection to the necessary medical institutions. Further studies are needed to assess the impact of frailty on elderly patients with COVID-19, to provide evidence-level recommendations in the effective execution of the process.

Conflict of Interest: The author has no conflict of interest related to this article.

Funding sources: The author declared that this study has received no financial support

Peer-review: Externally and internally peer reviewed.

\section{REFERENCES}

World Health Organization. Coronavirus disease 2019 [COVID-19] Situation Report-94 [Accessed 10 September 2020]. Available from: https://apps.who.int/iris/ handle/10665/331865

2. WHO Director-General's Opening Remarks at the Media Briefing on COVID-19: 11 March 2020. [Accessed 10 September 2020]. Available from: https://www.who.int/ $\mathrm{dg} / \mathrm{speeches/detail/who-director-general-s-opening-remarks-at-the-media-brief-}$ ing-on-covid-19---11-march-2020

3. WHO Coronavirus Disease (COVID-19) Dashboard. [Accessed 16 September 2020]. Available from: https://covid19.who.int/

4. Age, Sex, Existing Conditions of COVID-19 Cases and Deaths [Accessed 10 September 2020]. Available from: https://www.worldometers. info/coronavirus/coronavirus-age-sex-demographics/

5. Keskek SO, Erdogan H. COVID-19: A Current Brief Review. Acta Med. Alanya 2020;4(2):197-202. doi: 10.30565/medalanya.747238
6. Gold MS, Sehayek D, Gabrielli S, Zhang X, McCusker C, Ben-Shoshan M. COVID-19 and comorbidities: A systematic review and meta-analysis. Postgrad Med. 2020;132(8):749-55. doi: 10.1080/00325481.2020.1786964

7. Fulop T, Larbi A, Witkowski JM, McElhaney J, Loeb M, Mitnitski A et al. Aging, frailty and age-related diseases. Biogerontology. 2010;11(5):547-63. doi: 10.1007/ s10522-010-9287-2

8. Maltese G, Corsonello A, Di Rosa M, Soraci L, Vitale C, Corica F et al. Frailty and COVID-19: A systematic scoping review. J Clin Med. 2020;9(7):1-12. doi: 10.3390/ jcm9072106

9. Khezrian M, Myint PK, McNeil C, Murray AD. A review of frailty syndrome and its physical, cognitive and emotional domains in the elderly. Geriatrics. 2017;2(4):110. doi:10.3390/geriatrics2040036

10. Buckinx F, Rolland Y, Reginster JY, Ricour C, Petermans J, Bruyere O. Burden of frailty in the elderly population: Perspectives for a public health challenge. Arch Public Health. 2015;73(1):1-7. doi: 10.1186/s13690-015-0068-x. eCollection 2015.

11. Xue QL. The frailty syndrome: Definition and natural history. Clin Geriatr Med. 2011;27(1):1-15. doi: 10.1016/j.cger.2010.08.009

12. Chen X, Mao G, Leng SX. Frailty syndrome: An overview. Clin Interv Aging. 2014:9:433-41. doi: 10.2147/CIA.S45300. eCollection 2014

13. Clegg A, Young J, lliffe S, Rikkert MO, Rockwood K. Frailty in elderly people. Lancet. 2013:381:752-62. doi: 10.1016/S0140-6736(12)62167-9

14. Sternberg SA, Schwartz AW, Karunananthan S, Bergman H, Clarfield AM The identification of frailty: A systematic literature review. J Am Geriatr Soc. 2011;59(11):2129-38. doi: 10.1111/j.1532-5415.2011.03597.x

15. Smart R, Carter B, McGovern J, Luckman S, Connelly A, Hewitt J et al. Frailty exists in younger adults admitted as surgical emergency leading to adverse outcomes. $J$ Frailty Aging. 2017;6(4):219-23. doi: 10.14283/ffa.2017.28

16. Alkan ŞB, Rakıcıoğlu N. Nutrition in Frail Elderly Patients. Sdü Sağlık Bilim Derg. 2019;10(2): 184-9 doi: 10.22312/sdusbed.424345

17. Collard RM, Boter H, Schoevers RA, Voshaar RCO. Prevalence of frailty in community-dwelling older persons: A systematic review. J Am Geriatr Soc. 2012;60(8):148792. doi: 10.1111/j.1532-5415.2012.04054.x

18. Akın S, Mazıcıoglu MM, Mucuk S, Gocer S, Şafak ED, Arguvanlı S et al. The prevalence of frailty and related factors in community- dwelling Turkish elderly according to modified Fried Frailty Index and FRAIL scales. Aging Clin Exp Res. 2015;27(5):703-9. doi: 10.1007/s40520-015-0337-0

19. Özdemir S, Öztürk ZA, Türkbeyler IH, Şirin F, Göl M. Determination of Frailty Prevalence by Using Discrete Measures Geriatric Patients in Clinic. KSU Medical Journal. 2017;12(3):1-5. doi: 10.17517/ksutfd.338266

20. McDougall GJ. Delville CL. Becoming frail. In: Foreman MD, Milisen K, Fulmer TT, editor. Critical Care Nursing of Older Adults: Best Practices. Springer Publishing Company; 2010. p. 177-189.

21. Moccia F, Gerbino A, Lionetti V, Miragoli M, Munaron LM, Pagliaro $P$ et al. COVID-19-associated cardiovascular morbidity in older adults: A position paper from the Italian Society of Cardiovascular Researches. GeroScience. 2020;42(4):1021-49. doi: 10.1007/s11357-020-00198-w

22. Hewitt J, Carter B, Vilches-Moraga A, Quinn T, Braude P, Verduri A et al. The effect of frailty on survival in patients with COVID-19 (COPE): A multicentre, European, observational cohort study. Lancet Public Health. 2020;5(8):e444-51. doi: 10.1016/ S2468-2667(20)30146-8

23. Kojima G, lliffe $\mathrm{S}$, Walters K. Frailty index as a predictor of mortality: A systematic review and meta-analysis. Age Ageing. 2018;47(2):193-200. doi: 10.1093/ageing/ afx162

24. Cheng MH, Chang SF. Frailty as a risk factor for falls among community dwelling people: Evidence from a meta-analysis. J Nurs Scholarsh. 2017;49(5):529-36. doi: 10.1111/jnu.12322

25. Persico I, Cesari M, Morandi A, Haas J, Mazzola P, Zambon A et al. Frailty and delirium in older adults: A systematic review and meta-analysis of the literature. $J$ Am Geriatr Soc. 2018;66(10):2022-30. doi:10.1111/jgs.15503

26. Kojima G. Frailty as a predictor of disabilities among community-dwelling older people: A systematic review and meta-analysis. Disabil Rehabil. 2017:39(19):1897908. doi: 10.1080/09638288.2016.1212282

27. Bandeen-Roche K, Seplaki CL, Huang J, Buta B, Kalyani RR, Varadhan R et al. Frailty in older adults: A nationally representative profile in the united states. $J$ Gerontol A Biol Sci Med Sci. 2015;70(11):1427-34. doi: 10.1093/gerona/glv133

28. Mulla E, Montgomery U. Frailty: An overview. InnovAit. 2020;13(2):71-79. doi: 10.1177/1755738019890891

29. Kapucu S, Ünver G. Kırılgan Yașlı ve Hemșirelik Bakımı. Osmangazi Journal of Medicine. 2017:39:122-9. dol: 10.20515/otd 288967

30. Perrotta F, Corbi G, Mazzeo G, Boccia M, Aronne L, D'Agnano V et al. COVID-19 and the elderly: Insights into pathogenesis and clinical decision-making. Aging Clin Exp Res. 2020;32:1599-608. doi: 10.1007/s40520-020-01631-y

31. Rockwood K, Song X, MacKnight C, Bergman H, Hogan DB, McDowell I et al. A global clinical measure of fitness and frailty in elderly people. CMAJ. 2005;173(5):489-95. doi: 10.1503/cmaj.05005

32. Fried LP, Tangen CM, Walston J, Newman AB, Hirsch C, Gottdiener $\mathrm{J}$ et al. Frailty in older adults: Evidence for a phenotype. J Gerontol A Biol Sci Med Sci. 2001;56(3):M146-56. doi: 10.1093/gerona/56.3.m146

33. Morley J, Malmstrom T, Miller DA. Simple frailty questionnaire (FRAIL) predicts outcomes in middle aged african americans. J Nutr Health Aging. 2012;16(7):601-8. doi: 10.1007/s12603-012-0084-2

34. Ensrud KE, Ewing SK, Taylor BC, Fink HA, Cawthon PM, Stone KL et al. Com- 
parison of 2 frailty indexes for prediction of falls, disability, fractures, and death in older women. Arch Intern Med. 2008;168(4):382-9. doi: 10.1001/archinternmed.2007.113

35. Rolfson DB, Majumdar SR, Tsuyuki RT, Tahir A, Rockwood K. Validity and reliability of the Edmonton Frail Scale. Age Ageing. 2006;35(5):526-9. doi: 10.1093/ageing/ afl041

36. Kaeppeli T, Rueegg M, Dreher-Hummel T, Brabrand M, Kabell-Nissen, S, Carpenter $\mathrm{CR}$ et al. Validation of the clinical frailty scale for prediction of thirty-day mortality in the emergency department. Ann Emerg Med. 2020;76(3):291-300. doi:10.1016/j. annemergmed.2020.03.028

37. NICE guideline (NG159). COVID-19 rapid guideline: Critical care in adults. Published: 20 March 2020 .

38. Gardiner PA, Mishra GD, Dobson AJ. Validity and responsiveness of the FRAIL scale in a longitudinal cohort study of older Australian women. J Am Med Dir Assoc. 2015;16(9):781-3. doi: 10.1016/j.jamda.2015.05.005

39. Díaz de León González E, Gutiérrez Hermosillo H, Martinez Beltran JA, Chavez JHM, Palacios Corona R, Salinas Garza DP et al. Validation of the FRAIL scale in Mexican elderly: Results from the Mexican Health and Aging Study. Aging Clin Exp Res. 2016;28(5):901-8. doi: 10.1007/s40520-015-0497-y

40. Dong L, Qiao X, Tian X, Liu N, Jin Y, Si H et al. Cross-cultural adaptation and validation of the FRAIL scale in chinese community-dwelling older adults. J Am Med Dir Assoc. 2018;19(1):12-7. doi: 10.1016/j.jamda.2017.06.011

41. Hubbard RE, Maier AB, Hilmer SN, Naganathan V, Etherton-Beer C, Rockwood K. Frailty in the face of COVID-19. Age Ageing. 2020;49(4):499-500. doi: 10.1093/ ageing/afaa095

42. Baker KF, Hanrath AT, van der Loeff IS, Tee SA, Capstick R, Marchitelli G et al. COVID-19 management in a UK NHS foundation trust with a high consequence infectious diseases centre: A detailed descriptive analysis. Med Sci. 2021;9(1):1 13. doi: 10.3390/medsci9010006

43. Brill SE, Jarvis HC, Ozcan E, Burns TLP, Warraich RA, Amani LJ et al COVID-19: A retrospective cohort study with focus on the over-80s and hospital-onset disease. BMC Med. 2020;18(194):1-9. doi: 10.1186/s12916-020-01665-Z

44. Hoek RAS, Manintveld OC, Betjes MGH, Hellemons ME, Seghers L, Van Kampen JAA et al. COVID-19 in solid organ transplant recipients: A single-center experience. Transpl Int. 2020;33(9): 1099-105. doi: 10.1111/tri.13662

45. Bellelli G, Rebora P, Valsecchi MG, Bonfanti P, Citerio G, COVID-19 Monza Team members. Frailty index predicts poor outcome in COVID-19 patients. Intensive Care Med. 2020;46(8):1634-6. doi: 10.1007/s00134-020-06087-2

46. Turner J, Hodgson LE, Leckie T, Eade L, Ford-Dunn, S. A dual-center observational review of hospital-based palliative care in patients dying with COVID-19. J Pain Symptom Manage. 2020;60(2):e75-8. doi: 10.1016/j.jpainsymman.2020.04.031

47. Smet RD, Mellaerts B, Vandewinckele H, Lybeert P, Frans E, Ombelet $\mathrm{S}$ et al Frailty and mortality in hospitalized older adults with COVID-19: Retrospective observational study. J Am Med Dir Assoc. 2020;21(7):928-932.e.1. doi: 10.1016/j. jamda.2020.06.008

48. Nickel $\mathrm{CH}$, Ruegg M, Pargger $\mathrm{H}$, Bingisser R. Age, comorbidity, frailty status: ef fects on disposition and resource allocation during the COVID-19 pandemic. Swiss Med Wkly. 2020;150:w20269. doi: 10.4414/smw.2020.20269

49. Woo J, Leung J, Zhang T. Successful aging and frailty: Opposite sides of the same coin? J Am Med Dir Assoc. 2016;17(9):797-801. doi: 10.1016/j.jamda.2016.04.015

50. Boreskie KF, Hay JL, Duhamel TA. Preventing frailty progression during the COVID-19 pandemic. J Frailty Aging. 2020;9(3):130-1. doi: 10.14283/jfa.2020.29

\begin{tabular}{|l|l|}
\hline Author/ORCID & Authorship Contrubition \\
\hline $\begin{array}{l}\text { Hatice Yüceler Kaçmaz } \\
\text { 0000-0003-4529-1991 }\end{array}$ & $\begin{array}{l}\text { Consept and design, literature review, } \\
\text { manuscript writing, critical review, final } \\
\text { approval. }\end{array}$ \\
\hline $\begin{array}{l}\text { Ayser Döner } \\
\text { 0000-0002-3450-7219 }\end{array}$ & $\begin{array}{l}\text { Consept and design, literature review, } \\
\text { manuscript writing, critical review, final } \\
\text { approval. }\end{array}$ \\
\hline $\begin{array}{l}\text { Özlem Ceyhan } \\
\text { 0000-0002-1869-8713 }\end{array}$ & $\begin{array}{l}\text { Consept and design, interpretation, } \\
\text { supervision, critical review, final approval. }\end{array}$ \\
\hline
\end{tabular}

